\title{
A Critical Analysis of Collaborative Law as a Dispute Settlement Mechanism
}

\author{
Ni Wayan Desi Aryanti* \\ University College London, England-the United Kingdom
}

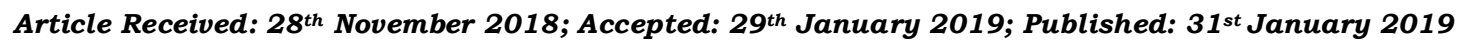

\begin{abstract}
The increasing number of practitioners who employ Collaborative Law as an alternative dispute resolution method indicates its relevance in resolving legal cases, especially in the field of Family Law. Following its incorporation into legislation in some States in the United States of America, the current practice of Collaborative Law seems to run further than what was developed in 1990 by a family lawyer, Stuart Webb in Minneapolis. This article attempts to expose that while Collaborative Law is beneficial in resolving family disputes, its distinct feature-disqualification provision poses some drawbacks to disputants. Besides, it assesses how clients screening and combining Collaborative Law with mediation can minimize disqualification provision's disadvantages. Lastly, this article examines why Collaborative Law's application in non-family disputes is limited.
\end{abstract}

Keywords: Collaborative Law; Family Law; Alternative Dispute Resolution

How to cite (Chicago-16th): Aryanti, Ni Wayan Desi. "A Critical Analysis of Collaborative Law as a Dispute Settlement Mechanism." Udayana Journal of Law and Culture 3, no. 1, 77-94. https://doi.org/10.24843/UJLC.2019.v03.i01.p04

doi: https://doi.org/10.24843/UJLC.2019.v03.i01.p04

*Email/Corresponding Author: niwayandesi@gmail.com and ni.aryanti.17@ucl.ac.uk 


\section{Introduction}

Collaborative Law is an alternative dispute resolution method which was developed in 1990 by a family lawyer, Stuart Webb in Minneapolis. ${ }^{1}$ Its most distinctive feature is the disqualification provision which prohibits parties' lawyers from representing their clients any further if the dispute goes into court. ${ }^{2}$ Since its establishment, it has been well received in family disputes. Texas in 2001 became the first state in the United States of America which enforced Collaborative Law through its legislation; followed by North Carolina in 2003. 3 In 2011, The International Academy of Collaborative Professionals (IACP) had 4,200 practitioners, and 300 practice groups registered members. ${ }^{4}$

Collaborative Law is said to be highly effective in resolving family disputes. The IACP's research in 2009-2010 showed that it solved 90\% of family law cases. ${ }^{5}$ However, there are critics of Collaborative Law. Lande said that it may inappropriately force parties to settle and therefore raises ethical concern. ${ }^{6}$ Rack Jr. argued that it may not be applicable in resolving all types of family disputes. ${ }^{7}$ Moreover, despite the impressive use of Collaborative Law in resolving family disputes, its application in non-family disputes is limited. 8

It can be acknowledged that John Lande is one of the scholars who has written about Collaborative Law in the last two decades. In 2003 he published an article 'Possibilities for Collaborative Law: Ethics and Practice of Lawyer Disqualification and Process Control in A New Model of Lawyering' and in 2011 introduced 'An Empirical Analysis of Collaborative Practice'

In the context of Collaborative Family Law, we may cite a work by Pauline H. Tesler ${ }^{9}$ and another work by Elena B. Langan, especially on the

1 John Lande, "An Empirical Analysis of Collaborative Practice," Family Court Review 49, no. 2 (2011): 257-281.

2"Uniform Collaborative Law Rules and Uniform Collaborative Law Act (Last Revised or Amended in 2010)," Family Law Quarterly 48, no. 1 (2014): 55-177.

3 Larry R. Spain, "Collaborative Law: A Critical Reflection on Whether a Collaborative Orientation Can Be Ethically Incorporated into the Practice of Law," Baylor L. Rev. 56 (2004): 141-172.

4 John Lande (2011), op.cit., 1.

5 Unpublished Description of IACP Research, Information Sheet, FAQ Based on Cases Reported to the International Academy of Collaborative Professionals Research Project (Oct. 25, 2009), ibid, 16.

6 John Lande, "Possibilities for Collaborative Law: Ethics and Practice of Lawyer Disqualification and Process Control In A New Model of Lawyering," Ohio St. LJ 64 (2003): 1315-1379.

7 Robert W Rack Jr, "Settle or Withdraw: Collaborative Lawyering Provides Incentive to Avoid Costly Litigation," Disp. Resol. Mag (1998): 8-9.

8 David A. Hoffman, "Collaborative Law in the World of Business," The Collaborative Law Review 6 (2003): 1.

9 Pauline H. Tesler, "Collaborative Family Law," Pepp. Disp. Resol. LJ 4 (2003): 317-336. 
issue of Divorce Disputes'. ${ }^{10}$ Some papers also highlight the ethical issue with regards to collaborative law, among others, writing by Larry R. Spain ${ }^{11}$ and Bobette Wolski. ${ }^{12}$

This article argues that while Collaborative Law's approach is beneficial in resolving family disputes, its distinct feature-disqualification provision poses some drawbacks to disputants. Furthermore, it assesses how clients screening and combining Collaborative Law with mediation can minimise disqualification provision's disadvantages. Finally, it examines why Collaborative Law's application in non-family disputes is limited.

This article reflects legal research in the field of alternative dispute resolution. The discussion very much relies on legal scholars' concepts and theories on the issues discussed. It also relies on some relevant sources e.g Family Law Council's Report to the Attorney-General and the views of the Ethics Committee in Colorado.

\section{Result and Discussion}

\subsection{Collaborative Law's Approaches to Resolving Disputes}

Collaborative Law starts with collaborative lawyers assisting clients to find their interest and educate them to manage conflict and emotion which enable them to participate directly in good faith negotiations. ${ }^{13}$ Parties then sign a participation agreement to demonstrate their commitment to good faith negotiation and voluntary disclosure of information aiming to preserve long-term relationships among them. ${ }^{14}$ Collaborative Law requires the involvement of parties and their lawyers throughout the negotiation process.

Its characteristics resemble Fisher and Ury principled negotiation, which suggests that people should negotiate based on merits, invent as many options as possible for mutual gains and when their interests are conflicted they should apply a standard which is independent of the will of the parties. ${ }^{15}$ Principled negotiation, which focuses on parties' interests, will typically result in an agreement which fairly satisfies parties' interests, is durable, and is more likely to be complied with by the parties. ${ }^{16}$ Family disputes are concerned about long-term relationships, and usually involves

10 Elena B. Langan, "We Can Work it Out: Using Cooperative Mediation-A Blend of Collaborative Law and Traditional Mediation-to Resolve Divorce Disputes," Rev. Litig. 30 (2010): 245-316.

11 Larry R. Spain, loc.cit.

12 Bobette Wolski, "Collaborative Law: An (un) Ethical Process for Lawyers?," Legal Ethics 20, no. 2 (2017): 224-241. https://doi.org/10.1080/1460728x.2017.1397401

13 Pauline H. Tesler, op.cit., 328.

14 Ibid.

15 Roger Fisher, William L. Ury, and Bruce Patton. Getting to Yes: Negotiating Agreement without Giving in (Penguin, 2011), 11-12.

16 Ibid, 7, 12. 
children who become the parties' common interest; hence, the above result is generally sought by parties in family dispute.

Principled negotiation, however, requires trust and good faith, which in some negotiations are absent. ${ }^{17}$ The absence of trust and good faith will induce parties to carry out position negotiation as they will conceal facts, expectations and underlying interest out of fear that the other party will employ it for their own benefit. Hence, while it looks ideal at the outset, its implementation is quite challenging.

Collaborative Law is different from mediation, which involves two parties and one neutral mediator with minimum involvement of lawyers in family law dispute. ${ }^{18}$ Lawyers' limited participation in mediation exacerbates power imbalance between the parties. ${ }^{19}$ Thus, it adversely affects the weaker party. Collaborative Law, on the other hand, resolves family disputes effectively by overcoming challenges in the implementation of principled negotiation and mediation through the ways noted below.

\subsubsection{Participation Agreement}

Karen Walch 20 years of study among her global students found that $40 \%$ of people think that they are cooperative and trusting. ${ }^{20}$ However, they believe that their counterpart is not cooperative and will only try to win the negotiation. ${ }^{21}$ This study demonstrates that there is a trust issue in negotiation among the parties, in which they believe that their counterpart only wants to benefit from them and does not want to cooperate to reach an amicable settlement. Such a situation will prevent parties from engaging in principled negotiation and instead resort to positional negotiation. Positional negotiation is detrimental to parties as it is inherently adversarial and focuses on positions which can result in negotiations becoming no more than a zero-sum game.

Collaborative Law addresses this issue through the participation agreement. A participation agreement is an agreement signed by the parties in which they commit to good faith negotiation, the exchange of accurate and honest information and undertake not to resort to litigation. ${ }^{22}$ The parties' commitment to not take the matter into court is reflected through disqualification provision. It prevents each parties' lawyer from representing

17 Jacqueline Nolan-Haley. Alternative Dispute Resolution in a Nutshell, 4th (West Academic, 2013), 27

18 Pauline H. Tesler, op.cit., 328.

19 John Lande (2003), op.cit., 1324.

20 Keld Jensen, Why Negotiators Still Aren't 'Getting To Yes'. Forbes, January 11, 2018, https://www.forbes.com/sites/keldjensen/2013/02/05/why-negotiators-still-arentgetting-to-yes /\#24009b7a2640

21 Ibid.

22 Donald A., Glenn, Thomas F. Burrage, Donald DeGrazia, and William Stewart. Family Law Services Handbook: The Role of the Financial Expert. (John Wiley and Sons, 2010), 288. 
them once the case goes to court. ${ }^{23}$ The parties would only be able to resort the matter to court if the Collaborative Law process is determined as failed and disqualification provision entered into force. A written agreement which expresses their commitment and the risk of losing their lawyers should a settlement not be reached, provide more incentives for parties to engage in good faith discussion. This eliminates, or at least minimises, trust issues between them.

\subsubsection{Disqualification Provision}

The main feature of Collaborative Law is the disqualification provision which distinguishes it from other alternative dispute resolution methods such as negotiation and mediation. The disqualification provision is a provision in the participation agreement which requires a parties' lawyer and experts who are appointed in the process to withdraw from their representation if the negotiation fails and the case proceeds to court. ${ }^{24}$ Negotiation and mediation do not have such a provision; and parties are allowed to proceed the matter to court with their existing lawyers. Such a provision is critical to screening disputants who are serious about resolving their dispute. It enables the parties to focus on good faith resolution and creates a forum which allows them to disclose true and honest information. ${ }^{25}$ If parties are not committed to settling the dispute through good faith negotiation they will not have entered into this process. The disqualification provision will make them lose their lawyers when negotiation fails, hence there is more risk for them if the negotiation is unsuccessful.

A disqualification provision is claimed to incentivise disputants to reach an early settlement, because in the event they proceed to litigation, they have to incur a duplicative cost to educate new lawyers about the dispute. This will increase litigation cost. ${ }^{26}$ Furthermore, as the participation agreement also requires all professionals involved in the collaborative process to withdraw if the matter goes into court, ${ }^{27}$ parties will incur further costs for experts as they cannot make use of such experts' advice at trial.

Reasonable disputants will consider the amount of time and money which they have already spent during the collaborative process. Such extra cost and physiological cost of reliving unpleasant experiences all over again

${ }^{23}$ Ibid.

24 Uniform Collaborative Law Rules and Uniform Collaborative Law Act (Last Revised or Amended in 2010), op.cit., 3.

25 Sherrie R. Abney, Why Would Anyone Use Civil Collaborative Law? American Bar Association, march 31, 2018, https://www.americanbar.org/content/dam/aba/publications/dispute_resolution_magazin e/Abney_Why_Use_GVB_edit.authcheckdam.pdf

26 John Lande (2013), op.cit., 1353. 4.

27 International Academy of Collaborative Professionals, 'Standards and Ethics' (2017), 
to new lawyers and experts 28 will reduce litigation's attractiveness to disputants and therefore will provide them with incentives to settle the dispute during the collaborative process. As for lawyers, the disqualification agreement will prevent them from quickly deciding that the case should be referred to litigation in the case of an apparent impasse 29 because their representation will be terminated once the case goes to court. Furthermore, it provides professional's achievement as they can prevent the adversity of failure. ${ }^{30}$ Thus, there are no incentives for lawyers to proceed with the matter to litigation.

Lande's research further demonstrated that $80 \%$ of collaborative lawyers believe that the disqualification provision helps parties to signal that they aim to make a good faith settlement, while $90 \%$ believed that it motivates parties to take additional efforts to reach a settlement in order to avoid litigation 31 Sefton's research also supports the above statement. ${ }^{32}$ Although lawyers reported that it raised clients' concerns of losing their lawyers if they have to litigate, lawyers convinced them that Collaborative Law would work if parties are screened and prepared accordingly. 33

Nevertheless, clients see the disqualification agreement rather differently than do lawyers. Schwab's survey ${ }^{34}$ described that only $45 \%$ of clients who reached agreement through Collaborative Law believed that disqualification provision keeps them in the negotiating process when they would have otherwise litigated. ${ }^{35}$ Looking only at that number, it seems that the disqualification provision is not a significant factor for the parties who choose Collaborative Law. However, that survey was conducted after settlements were reached and it did not explain whether there were other reasons why the $55 \%$ stayed in the negotiation process. Such a distinction is essential. If they decided to continue the negotiation (when they would have otherwise proceeded to court) due to consideration of duplicative costs which arise as a result of lawyers' withdrawal, then the disqualification

28 John Lande (2013), op.cit., 1344.

29 It is due to their impatience and result oriented attitude. Pauline H. Tesler, op.cit., 320.

30 Family Law Council. "Collaborative Practice in Family Law: A Report to the AttorneyGeneral Prepared by the Family Law Council." (2007), 58

31 John Lande (2011), op.cit., 5.

32 Lawyers considered that disqualification provision will make parties to 'think twice' before terminating negotiation process, therefore it helps to build commitment to good faith settlement between them. Ibid, 15 .

33 Ibid.

34 William H. Schwab, "Collaborative Lawyering: A Closer Look at an Emerging Practice." Pepperdine Dispute Resolution Law Journal 4, no. 3 (2004): 370. Response Rates and Composition of the Samples: Of the 367 surveys sent to lawyers, nine were returned as undeliverable and seventy-one were at least partially completed, for a response rate of 19.8\%. Participation varied by group, ranging from $12.5 \%$ in Florida to $29.8 \%$ in Minnesota. 35 William H. Schwab, op.cit., 379. 
provision played a significant role in keeping parties at the negotiation table. Furthermore, as the study was conducted after disputes were resolved, it did not indicate whether the disqualification provision was an insignificant factor to the disputants when deciding to opt for Collaborative Law to resolve their dispute. ${ }^{36}$ Hence, the disqualification provision performs a significant role in incentivizing parties to reach a settlement.

\subsubsection{Disclosure of True and Honest Information}

Another characteristic of Collaborative Law is the disclosure of true and honest information. Under a participation agreement, parties are required to reveal all relevant and material information which are required by the parties to make a decision with regard to the dispute. ${ }^{37}$ Exchange of information can be made without formal request. 38 Moreover, the disqualification provision requires lawyers, financial advisers and professionals who are involved in Collaborative Law to resign if their clients intentionally withhold material information or disclose wrong information. 39 Hence, this increases the risk of making misrepresentations and facilitates the exchange of true and honest information between parties.

Such a feature effectively overcomes challenges in the implementation of principled negotiation and mediation. During mediation or negotiation, a party may withhold or divulge false information and their counterpart cannot conduct cross-examination to discover if such information is true. Effective negotiation requires the efficient exchange of information between parties, as it will allow them to learn each other's underlying interests and find common interest which leads into the mutually acceptable settlement. 40 The assurance that parties will disclose true and honest information will facilitate effective negotiation between them. With more incentives to divulge true information, Collaborative Law facilitates effective negotiation between the parties.

\subsubsection{Appointment of Joint Neutral Experts}

Appointment of joint neutral experts is the development of Collaborative Law through the interdisciplinary team approach. ${ }^{41}$ Parties may appoint a joint neutral expert such as financial expert or physiologist to assist them. A divorce coach assists disputant in emotional management

36 Ibid.

37 International Academy of Collaborative Professionals, 4.

38 Bobette Wolski, op.cit., 228.

39 International Academy of Collaborative Professionals, 13.

40 Roberts and Palmer posit that for a negotiation to take place, it requires a medium of communication which allows the exchange of information, successful communication about each party's goals and identification and evaluation of available options by the parties. Simon Roberts and Michael Palmer. Dispute Processes: ADR and the Primary Forms of Decision-Making (Cambridge University Press, 2005), 113.

41 Pauline H. Tesler, op.cit., 330-331. 
and effective communication. ${ }^{42} \mathrm{~A}$ child specialist procures a balanced view concerning a child's needs and parenting plans, while a financial expert aids disputants in budget concerns, addressing financial issues and explaining the consequences of a certain financial arrangement plan. ${ }^{43}$ The involvement of joint neutral experts will provide parties with 'value added' advice which can prevent them from short term consideration settlement. ${ }^{44}$ Furthermore, the appointment of neutral experts will help disputants by eliminating conflicting experts' opinions and save costs, as they only need to appoint one expert. 45 While the involvement of experts can assist parties in the negotiation, it can be argued that such involvement will increase the cost that has to be borne by the parties. However, where a dispute requires expert opinion (for example in case of valuation of joint properties), having one neutral expert whose fee is to be shared by the parties will reduce cost. Additionally, as experts are also subject to the disqualification provision and their opinion cannot be used for litigation purposes, it will increase the cost of litigation, thus making litigation less attractive and promote greater incentive for settlement.

Compared to principled negotiation, Fisher and Ury also suggest the use objective criteria which may derive from expert opinion during negotiation. ${ }^{46}$ Their approach, however, does not address a situation where there are different objective criteria as the result of the appointment of two different experts. Appointment of joint experts will eliminate such an issue, as there will only be one joint expert who will provide parties with an objective standard.

\subsubsection{Continuous Involvement of Lawyers During Collaborative Process}

In a dispute, parties may not be able to articulate their interest and desires efficiently due to power imbalance, negotiation skills or emotions. In this case, Gilson and Mnookin suggested that lawyers can facilitate cooperation between parties when they are unable to do so. ${ }^{47}$ The presence of lawyers will assist parties to effectively communicate their underlying interest during a negotiation in a constructive manner. ${ }^{48}$ Keet's research also demonstrated that the negotiation environment improved when lawyers and disputants work together. ${ }^{49}$ This feature makes Collaborative Law more

42 Pauline H. Tesler, op.cit., 331.

43 Ibid.

44 Ibid.

45 William H. Schwab, op.cit., 359-360.

46 Roger Fisher, William L. Ury, and Bruce Patton, op.cit., 11.

47 Ronald J. Gilson and Robert H. Mnookin, "Disputing through Agents: Cooperation and Conflict between Lawyers in Litigation," Columbia Law Review 94, no. 2 (1994): 512.

48 Donald A., Glenn, Thomas F. Burrage, Donald DeGrazia, and William Stewart, op.cit., 290.

49 John Lande (2011), op.cit., 11. 
appealing compared to arbitration or mediation. ${ }^{50} \mathrm{In}$ arbitration, the binding decision is made by arbitrators who serve as neutral fact finders, making the parties feel that they have no control over the process. ${ }^{51}$ In mediation, the mediator is expected to be a neutral third party who will only provide limited legal advice to parties; hence, insufficient to manage power imbalance between parties. ${ }^{52}$ Furthermore, the absence of a requirement for parties to have lawyers and the limited participation of lawyers during the mediation process exacerbate power imbalances. 53 Thus, Collaborative Law enables disputants to control the process while at the same time ensures that they have legal advisors at their side who can advise them of the legal consequences of their decisions during the negotiation and therefore can manage power imbalance.

The aforementioned characteristics of Collaborative Law make it effective to resolve family disputes and address negotiation and mediation's drawbacks. The Mapping Paths of Family Justice's research published in 2014 found that among alternative dispute resolutions, Collaborative Law provided disputants with the highest degree of satisfaction. ${ }^{54}$ It is also relatively fast, as $80 \%$ of the cases are resolved in less than one year. 55 However, there are also critics of the disqualification provision and its limited application outside family disputes.

\subsection{Critics of the Disqualification Provision}

\subsubsection{Compulsion to Settle}

The disqualification provision is at the heart of Collaborative Law and distinguishes Collaborative Law from the other form of alternative dispute resolution. The disqualification provision essentially requires the withdrawal of both of the lawyers in the event of: i) withdrawal of either party from the process; ii) parties are not acting in good faith by using litigation as a threat, and iii) clients divulge false information. 56 While Collaborative Law requires principled negotiation, the disqualification provision keeps the parties in negotiation and reaching an agreement. 57 However, that agreement may not necessarily be the one that satisfies both parties' interests.

While Collaborative Law has a high rate of settlements and such settlements are attributed to the disqualification provision, there has not

50 P. Oswin Chrisman, Gay G. Cox, and Petra Novotna, "Collaborative Practice Mediation: Are We Ready to Serve this Emerging Market," Pepp. Disp. Resol. LJ 6, no. 3 (2006): 454.

51 Ibid.

52 John Lande (2013), op.cit., 1324-1325.

53 Ibid

54 Jo Edwards, Amanda Sandys and Jamie Gaw, 'New Opportunities in Collaborative Practice,' Family Law Journal- Lexis Nexis 48 (2018): 330.

55 John Lande (2011), op.cit., 17.

56 Elena B Langan, op.cit., 281.

57 John Lande (2013), op.cit., 1364 
been a study which demonstrated that such settlement accommodates the parties' interests. If it is seen from another perspective, it might be that parties stay in the negotiation because they can no longer afford litigation. They have incurred a substantial amount of money and time during Collaborative Law and will incur duplicative costs of retaining new lawyers and experts for litigation. From the disputants' point of view, as the cost of litigation (which becomes their alternative to negotiated agreement) is exorbitant, they will be encouraged to accept a less valuable settlement. ${ }^{5}$ For example, Macfarlane's study found a case where a client had incurred USD 24,000 in lawyers' fees and had endured nine months of negotiation. ${ }^{59} \mathrm{In}$ that case, the client found it hard to terminate the negotiation process because of the cost that had been incurred and the cost which would be incurred to litigate with a new lawyer. ${ }^{60}$ Hence, the disqualification provision may prevent procedural fairness 61 and place disputants in a position where they settle because of cost and time constraints; which may not be in their best interest.

From the lawyers' perspective, because they enter into the contract with their clients for the sole purpose of settlement ${ }^{62}$, there is a considerable pressure for them to insist that their clients stay in negotiation and reach a settlement. A study conducted in 2004 found that $22 \%$ of collaborative lawyers believed that Collaborative Law puts pressure on clients, particularly on the weaker party. ${ }^{63}$ Moreover, as their contracts are going to be terminated once the case moves to court, there is a strong incentive for lawyers to push their clients to continue negotiation and urge a settlement. Thus, the pressure to settle comes in two forms; from the lawyer whose retainer contract relies on the ability to reach a settlement, and from the disputants' financial constraint which makes the cost of litigation exorbitant. In such a case, Collaborative Law does not facilitate the parties to achieve an agreement that accommodates their legitimate interests.

\subsubsection{Ethical Concern}

The disqualification provision further raises ethical concerns regarding lawyers' representation because it prohibits lawyers from exploring litigation as an option to resolve disputes. ${ }^{64}$ The ethical issue may arise when it is not in the client's best interest to settle, but if the case is not

58 Ibid.

59 Julie Macfarlane, "Experiences of Collaborative Law: Preliminary Results from the Collaborative Lawyering Research Project." J. Disp. Resol. (2004): 239.

60 Ibid.

61 Family Law Council, op.cit., 286.

62 Larry R. Spain, op.cit., 15.

63 Anna Sapountsis, 'Challenges of Collaborative Practice and the Commercial Context'. Civil justice.info, $\quad$ March $\quad 31, \quad 2018$. http: / / www.civiljustice.info/cgi/viewcontent.cgi?article=1000\&context=collab

64 Family Law Council, op.cit., 56. 
settled, the lawyers' representation will be terminated. Hence, there is a conflict of interest which may limit lawyers from giving the best advice which caters to their clients' interests. Such a situation does not arise in other forms of alternative dispute resolution which aim to achieve a settlement.65In negotiation and mediation, for example, lawyers will not face such issues as there is no requirement to terminate their contract when their clients decide to litigate. Hence, they have no incentive not to advice their client to litigate when it is in their client's best interest to do so.

Further, the Ethics Committee in Colorado stated that:

"It is the opinion of this Committee that the practice of Collaborative Law violates Rule 1.7(b) of Colorado Rules of Professional Conduct insofar as a lawyer participating in the process enters into a contractual agreement with the opposing party requiring the lawyer to withdraw in the event that the process is unsuccessful." 66

However, that issue can be managed through the participation agreement and the retainer agreement. Parties can provide in the participation agreement that each party shall terminate their lawyers if the case is referred to court. The lawyer's withdrawal from the process is governed by the retainer agreement between lawyer and client. Thus, lawyers do not have to enter into a contract with the opposing party which requires their withdrawal in the event of non-settlement.

Wolski also argues that another drawback of the disqualification provision is that it can be used by a manipulative party to terminate their counterpart's lawyers at the critical part of a negotiation. ${ }^{67}$ This is due to the nature of the disqualification provision which requires lawyers to terminate their contract with their clients in the event of withdrawal of either party from Collaborative Law. ${ }^{68}$ However, this criticism is anecdotal. The IACP's research demonstrated that $90 \%$ of family law cases ended up in settlements. ${ }^{69}$ Such a high settlement rate suggested that disputants do not manipulate disqualification provisions to terminate their counterpart's lawyers, because if they do, Collaborative Law would not be able to record such settlement rates. Furthermore, it may only occur in a very rare case of significant power imbalance in which one party is financially more powerful than the other party, and when their involvement in Collaborative Law is just aimed to drain the other party's financial resources. However, even in that situation, it will still be more efficient for that party to directly take the case to court. They can allocate their financial resources to win their case and save more time as they do not have to go through the negotiation

${ }^{65}$ Ibid.

66 Christopher M Fairman, "Growing Pains: Changes in Collaborative Law and the Challenge of Legal Ethics," Campbell L. Rev. 30 (2007): 250.

67 Bobette Wolski, op.cit., 237.

68 Ibid.

69 John Lande (2011), op.cit., 16. 
process. Thus, this drawback is not inherent in Collaborative Law and can be managed through client screening, which will be explained below.

\subsection{Managing Disqualification Provision's Drawbacks}

\subsubsection{Clients Screening}

The ethical issue related to a forced settlement resulting from a disqualification provision may arise because Collaborative Law is not a one size fits all mechanism to resolve all family disputes. Comes asserted that power imbalances, violence, drugs abuse and mental health issues will make Collaborative Law ineffective, or even worsen the underlying issues. ${ }^{70}$ This assertion is in line with Lande and Mosten's view. Lande and Mosten found that, in addition to power imbalance, drug abuse and mental health issues, lawyers should take into account trustworthiness, domestic violence, personal motivation and suitability of the parties when assessing the appropriateness of Collaborative Law to resolve a particular family dispute. ${ }^{71}$

Where the aforementioned situation occurs, Collaborative Law is unlikely to work. Even if they reach a settlement, it may be because of financial constraints which may not accommodate their interests. In such a case, it is pertinent for lawyers to screen their clients prior to enrolling them in Collaborative Law. The nature of Collaborative Law requires disputants who are willing to implement a non-adversarial approach. ${ }^{72}$ Initial screening will help lawyers decide whether a particular client is a suitable candidate for Collaborative Law. If they are suitable candidates, it is likely that they can reach a settlement which reflects their interest. Shefton's study found that lawyers believed that when clients are properly screened and prepared, Collaborative Law will likely to be effective. ${ }^{73}$ Hence, appropriate screening is essential in ensuring the success of Collaborative Law as well as in minimizing the ethical issues arising from the disqualification provision.

However, initial screening also poses some challenges. It may not be conducted in sufficient time because lawyers may not want to incur substantial unpaid time to do the screening. At the same time, clients may not want to incur the significant cost of screening only to find that they are not a suitable candidate for Collaborative Law.74 In such situations, initial screening may fail to detect the presence of drugs abuse, violence or power imbalance issues. ${ }^{75}$ This issue, however, is not inherent in Collaborative Law. ${ }^{76}$ It can be avoided by thorough screening and lawyers' commitment

70 Diana M. Comes, "Meet Me in the Middle: The Time is Ripe for Tennessee to Adopt the Uniform Collaborative Law Act," U. Mem. L. Rev. 41 (2010): 565.

71 John Lande (2011), op.cit., 12.

72 Joel M. Pratt, "Three Tiers for Collaborative Law: A Moderate Solution," Resolved: J. Alternative Disp. Resol. 5, no.2 (2015): 11.

73 John Lande (2011), op.cit., 15.

74 Joel M. Pratt, op.cit., 12.

75 Ibid.

76 Ibid. 
which allows them to make a fair judgement as to the suitability of a client to Collaborative Law. There is also an incentive for lawyers to conduct this screening. As a collaborative lawyers' sole objective is a settlement, client screening will aid them in achieving that objective. A suitable candidate who takes a non-adversarial approach in the negotiation will allow principled negotiation to occur; thus, resulting in a mutually acceptable settlement. Therefore, it is in the lawyers' interest to conduct a proper screening.

\subsubsection{Incorporating Mediation into Collaborative Law}

Another way to address the disqualification provision's drawback is by incorporating mediation into the Collaborative Law process. In the event of an impasse, instead of terminating the lawyers' representation and proceeding to court, parties can enter into a mediation process with the assistance of their existing lawyers. Incorporating mediation into the Collaborative Law will benefit clients in two ways:

1. Mediation will allow the involvement of an independent third party to resolve the dispute, while at the same time maintain a representation of their lawyers and service from existing experts. Hence, they do not have to incur duplicate costs.

2. Collaborative Law requires the continuous involvement of lawyers throughout the process (through four-ways meeting). The inclusion of mediation into the process will allow parties to reap the benefit of mediation, while at the same time it addresses power imbalance issues which usually arise in mediation due to limited involvement of lawyers during the process.

The Mapping Paths to Family Justice's study found that disputants prefer to resolve their disputes in an amicable manner with personal guidance and assistance when needed. ${ }^{77}$ Therefore, mediation can be done through five-ways meeting in which an independent third party mediates the case with the presence of lawyers throughout the process. This ensures that clients are always equipped with the support and advice of their lawyers. Cox's survey found that of twenty-eight cases which employ mediation in conjunction with Collaborative Law, none of them was terminated. ${ }^{78}$ Thus, combining mediation into Collaborative Law processes brings a positive impact. It provides parties with an alternative in the case of an impasse. They can avoid litigation and duplicative costs, while at the same time they are not pushed into an unwanted settlement.

\subsection{Limited Application of Collaborative Law in Non-Family Disputes}

As mentioned previously, while Collaborative Law is effective in resolving family disputes, its application in commercial disputes is rather

77 Jo Edwards, Amanda Sandys and Jamie Gaw, loc.cit.

78 P. Oswin Chrisman, Gay G. Cox, and Petra Novotna, op.cit., 460. 
limited. 79 The nature of commercial disputes and the resistance to Collaborative Law's characteristics may contribute to its limited application.

\subsubsection{Nature of Non-Family Disputes}

Collaborative Law requires principled negotiation to take place, and not all disputes can be resolved through principled negotiation. Parties in family disputes usually have a common interest and when children are involved, they want to maintain a long-term relationship. Such common interest may be children or financing the disputes from the same source of funds. 80 However, in non-family disputes, disputants may not have common interests, or their interests have substantially diverged. In case of tort, discrimination or sexual harassment, for example, the offender's interest is to keep the dispute settlement in private area, while claimant may want to settle the dispute through litigation because they want to send a message to the public. ${ }^{81}$ In such case, Collaborative Law will not be suitable for the parties to resolve their disputes and litigation is inevitable, because one party wants to obtain vindication, judgement and set a precedent which cannot be obtained from Collaborative Law.

A family dispute is likely to be a one-off case. Although divorce cases have become more common, it is unlikely that parties will be engaged in similar disputes in the future. Therefore, a law firm may be less concerned about referring a client in such a situation to another firm; when dispute proceeds to court. ${ }^{82}$ However, this is not the case with non-family disputes. Many commercial disputes involve the same parties ${ }^{83}$ which makes them long-term clients for a law firm. ${ }^{84}$ There will be more concern for a firm to refer their clients to another firm, as it will affect their source of income and there is a chance that the client will have the other firm to represent them in future disputes. This will affect the firm's potential income even further.

\subsubsection{Resistance to Collaborative Law's Feature}

The characteristic of Collaborative Law which refrains from litigation also contributes to the resistance of lawyers to use it in commercial disputes. Lawyers believe that litigation is their ultimate test. 85 It is conducted in public and presents them with a tremendous intellectual and emotional challenge. At the same time, it is also considered to be their biggest stream of revenue. 86

\footnotetext{
79 David A. Hoffman, op.cit., 1.

80 Ibid. 2.

81 Ibid.

82 Ibid.
}

${ }^{83}$ In international trade for examples, a certain party can engage in similar disputes with other parties. A ship provider can engage into charter party dispute with more than one of their charterers.

84 David A. Hoffman, op.cit., 2.

85 Ibid. 7.

${ }^{86}$ Ibid. 
Collaborative Law with its disqualification provision will prevent them from obtaining such exposure and benefits. Therefore, the firms may perceive it as threatening their livelihood. ${ }^{87}$ The result is resistance to the use of Collaborative Law in commercial disputes and limiting its application in non-family disputes.

\section{Conclusion}

In summary, the participation agreement and disqualification provision incentivize parties to engage in good faith discussion, exchange true and honest information and to reach a settlement. It is because the parties are at risk of losing their lawyers and having to incur a duplicative cost if the case proceeds to court. The involvement of experts and lawyers through four-way meeting also contributes to the high rate of settlement. However, the disqualification provision may create a financial constraint which forces parties into a settlement that does not reflect their interest. Furthermore, it also poses ethical issues. Lawyers may advise their client to litigate (even when it is in their client's best interest to do so), due to the nature of the disqualification provision; which requires termination of lawyers' representation in a case where the dispute is litigated. In such a case, client screening and the incorporation of mediation into Collaborative Law can minimize the unwanted impacts of the disqualification provision. Finally, while the aversion to litigation made Collaborative Law more effective in resolving a family dispute, such an approach is highly resisted in non-family disputes. The nature of such disputes may significantly differ from family disputes, and it limits firms' revenue stream which substantially derives from litigation. Hence, making Collaborative Law's application in non-family disputes is limited.

\section{Acknowledgement}

This article is an advanced version of an essay made by Author during her study at University College London, Master of Law Programme in 2018, on Alternative Dispute Resolution course (Code: LAWSG094). The author would like to express a great honour to John Lowry who taught this course and the British Government who funded the Author's study in the UK through Chevening Scholarship. Argument and opinion contained in this article is an academic view of the author and do not necessarily linked to Author's affiliation. 


\section{BIBLIOGRAPHY}

\section{Book}

Fisher, Roger, William L. Ury, and Bruce Patton. Getting to Yes: Negotiating Agreement without Giving in. Penguin, 2011.

Glenn, Donald A., Thomas F. Burrage, Donald DeGrazia, and William Stewart. Family Law Services Handbook: The Role of the Financial Expert. John Wiley and Sons, 2010.

Nolan-Haley, Jacqueline. Alternative Dispute Resolution in a Nutshell, 4th. West Academic, 2013.

Roberts, Simon, and Michael Palmer. Dispute Processes: ADR and the Primary Forms of Decision-Making. Cambridge University Press, 2005.

Council, Family Law. "Collaborative Practice in Family Law: A Report to the Attorney-General Prepared by the Family Law Council." (2007).

\section{Journal Article}

Comes, Diana M. "Meet Me in the Middle: The Time is Ripe for Tennessee to Adopt the Uniform Collaborative Law Act." U. Mem. L. Rev. 41 (2010): 551-595.

Chrisman, P. Oswin, Gay G. Cox, and Petra Novotna. "Collaborative Practice Mediation: Are We Ready to Serve this Emerging Market." Pepp. Disp. Resol. LJ 6, no.3 (2006): 451-464.

Edwards, Jo, Amanda Sandys and Jamie Gaw, 'New Opportunities in Collaborative Practice,' Family Law Journal- Lexis Nexis, 48 (2018): 330.

Fairman, Christopher M. "Growing Pains: Changes in Collaborative Law and the Challenge of Legal Ethics." Campbell L. Rev. 30 (2007): 237-273.

Gilson, Ronald J., and Robert H. Mnookin. "Disputing through Agents: Cooperation and Conflict between Lawyers in Litigation." Columbia Law Review 94, no. 2 (1994): 509-566. https://doi.org/10.2307/1123202

Hoffman, David A. "Collaborative Law in the World of Business." The Collaborative Review 6 (2003).

Langan, Elena B. "We Can Work it Out: Using Cooperative Mediation-A Blend of Collaborative Law and Traditional Mediation-to Resolve Divorce Disputes." Rev. Litig. 30 (2010): 245-316.

Lande, John. "An Empirical Analysis of Collaborative Practice." Family Court Review 49, no. 2 (2011): 257-281. https://doi.org/10.1111/j.17441617.2011.01369.x

Lande, John. "Possibilities for Collaborative Law: Ethics and Practice of Lawyer Disqualification and Process Control in a New Model of Lawyering." Ohio St. LJ 64 (2003): 1315-1379. 
Macfarlane, Julie. "Experiences of Collaborative Law: Preliminary Results from the Collaborative Lawyering Research Project." J. Disp. Resol. (2004): 179-226.

Pratt, Joel M. "Three Tiers for Collaborative Law: A Moderate Solution." Resolved: J. Alternative Disp. Resol. 5, no.2 (2015): 4-25.

Rack Jr, Robert W. "Settle or Withdraw: Collaborative Lawyering Provides Incentive to Avoid Costly Litigation." Disp. Resol. Mag (1998): 8-9.

Spain, Larry R. "Collaborative Law: A Critical Reflection on Whether a Collaborative Orientation Can Be Ethically Incorporated into the Practice of Law." Baylor L. Rev. 56 (2004): 141-172.

Schwab, William H. "Collaborative Lawyering: A Closer Look at an Emerging Practice." Pepperdine Dispute Resolution Law Journal 4, no. 3 (2004): 351-396.

Tesler, Pauline H. "Collaborative Family Law." Pepp. Disp. Resol. LJ 4 (2003): 317-336.

"Uniform Collaborative Law Rules and Uniform Collaborative Law Act (Last Revised or Amended in 2010)." Family Law Quarterly 48, no. 1 (2014): 55-177.

Wolski, Bobette. "Collaborative Law: An (un) Ethical Process for Lawyers?." Legal Ethics 20, no. 2 (2017): 224-241. https://doi.org/10.1080/1460728x.2017.1397401

\section{Other Documents}

Unpublished Description of IACP Research, Information Sheet, FAQ Based on Cases Reported to the International Academy of Collaborative Professionals Research Project (Oct. 25, 2009),

International Academy of Collaborative Professionals, 'Standards and Ethics' (2017)

\section{Website Content}

Abney, Sherrie R. Why Would Anyone Use Civil Collaborative Law?. American Bar Association, march 31, 2018, https://www.americanbar.org/content/dam/aba/publications/dispute _resolution_magazine/Abney_Why_Use_GVB_edit.authcheckdam.pdf

Jensen, Keld. Why Negotiators Still Aren't 'Getting To Yes'. Forbes, January 11 , 2018, https://www.forbes.com/sites/keldjensen/2013/02/05/whynegotiators-still-arent-getting-to-yes / \#24009b7a2640

Sapountsis, Anna. 'Challenges of Collaborative Practice and the Commercial Context'. Civil justice.info, March 31, 2018. http:/ / www.civiljustice.info/cgi/viewcontent.cgi?article $=1000 \&$ context $=$ $\underline{\text { collab }}$ 